\title{
Mapping Icing Rates on Sea-Going Ships
}

\author{
By W. Paul Zakrzewski, Ryan Blackmore and Edward P. Lozowski \\ Division of Meteorology, University of Alberta, Edmonton, Alberta, Canada \\ (Manuscript received 28 January 1988, in revised form 22 June 1988)
}

\begin{abstract}
Maps for ship icing potential distribution over the oceans are reviewed. Special attention is paid to maps presenting forecast icing rates on ships. The NOAA Experimental Ice Accretion map with a 24-hour categorical forecast of ice growth rate and the AES approach to mapping icing intensity are evaluated.

A new mathematical model for the growth of spongy saline ice on a ship's superstructure is presented in detail. This model calculates the icing rates over the entire front face of the ship's superstructure within the zone of spraying. The effect of the salinity of the moving water film and the ice sponginess are both taken into account. The model input is the ship speed and heading, the air temperature, the seawater salinity, the sea surface temperature, and the wind speed and fetch.

Computer-produced maps of the icing rates on the ship are produced for the cold waters east of Canada. The first results indicate that our new ship icing model could be applied for operational purposes (hindcasting and forecasting icing rates on ships) if an automated data acquisition system was available.
\end{abstract}

\section{Introduction}

Superstructure icing is well-known as an environmental factor that menaces shipping and fisheries. Medium and small ships, especially small cargo vessels and medium and small fishing vessels, are very prone to icing. On the average, 10 ships are lost due to icing every year (Aksyutin, 1979). On one occasion, ten fishing vessels capsized due to ice loads during an icing storm in the North Pacific Ocean (Shellard, 1974; Aksyutin, 1979). Under severe air-sea conditions, enough ice to cause the loss of ship stability can be accumulated within a few hours. In order to guard against capsizing, small ships can often do nothing but avoid areas of heavy icing or seek shelter in the lee of land. If ships cannot avoid heavy icing in the open sea, reducing the ship speed or heading downwind will result in a reduction of the icing intensity.

Reliable and clear forecasts of icing on ships, and some basic information on the climatology

(C) 1988, Meteorological Society of Japan of icing are essential for the safety of ships operating in cold oceans. Information on icing climatology (e.g., contours of the probability of potential icing) is usually published using graphical presentation, based on the spatial distribution of certain climatological characteristics over the ocean. Icing forecasts for shipping are produced and broadcast either in the form of weather messages and warnings issued by the appropriate weather services for various marine forecast areas, or in the form of facsimile maps of icing intensity. Although facsimile map receivers are not yet installed on every ship, a graphic presentation of icing intensities over the ocean gives navigators much more information than a worded weather message or warning: a facsimile map shows the spatial distribution of the icing intensity over large sea areas. This makes the analysis of the weather situation and its effects on the sailing conditions much easier. Of course, icing warnings and forecasts of icing intensity in the form of weather messages are still necessary 
for all ships, especially those not equipped with facsimile receivers.

Since the mapping of ship icing parameters has several advantages over the information available in weather messages (forecasts of icing), or information published for mariners in the form of tabulated data (tables), we will now review some possible approaches to the graphical presentation of ship icing information.

\section{Available Maps of Ship Icing-Related Para- meters}

\subsection{Ship icing climatology}

The areas of the North Atlantic and Pacific Oceans in which a ship can experience icing were first shown in several oceanographical atlases (U.S. Navy, Marine Climatic Atlas of the World, 1956; Oceanographic Atlas of the Polar Seas, 1958; USSR Morskoy Atlas, 1953). Harwood (1960) has compiled the information on spray icing potential given in the sea atlases. The areas of icing potential in a given month were determined as the zones between the average edge of pack ice of $5 / 10$ or more concentration, and the $10 \%$ frequency isoline of the zero degree isotherm. These analyses of the spatial distribution of the areas of icing potential, showed a dramatic change with the seasonal coverage of the sea ice. The maps of icing potential given in Harwood (1960) were also published by Dunbar (1964) and Minsk (1977). Minsk reviewed most of the reports on ship icing which were available by that time (including those produced by the Soviets). His report is well illustrated with several maps of icing potential.

Based mostly on the Oceanographic Atlas of the Polar Seas (1958), Smirnov (1972) discussed the hydrometeorological conditions of ship icing in the North Atlantic. Contours of the frequencies of icing potential for the ship hull, and for the ship superstructure, were drawn using the assumption that the ice accumulates due to freezing of spray on the ship hull if the air temperature is $\mathrm{T}<-1.7^{\circ} \mathrm{C}$ and the wind speed is $\mathrm{V} \geqq 8.2 \mathrm{~m} \mathrm{~s}^{-1}$, and on the ship superstructure if $\mathrm{T}<-2.2^{\circ} \mathrm{C}$ and $\mathrm{V} \geqq 8.7 \mathrm{~m} \mathrm{~s}^{-1}$. The frequencies were calculated using the mean monthly values of these parameters over the ocean.

The probability of meteorological conditions favourable to spray icing on ships in the Chukchi Sea and in the Bering Strait for the July-October period, were calculated by Kolosova (1972). The conditions resulting in icing were assumed to be $\mathrm{T}<0^{\circ} \mathrm{C}$ and $\mathrm{V} \geqq 8 \mathrm{~m} \mathrm{~s}^{-1}$. Severe icing was assumed if $\mathrm{T}<0^{\circ} \mathrm{C}$ and $\mathrm{V} \geqq 15 \mathrm{~m} \mathrm{~s}^{-1}$. A similar study was completed for the Kara Sea (Kolosova et al., 1971).

Potential icing on ships in the Atlantic Ocean was studied by DeAngelis (1974). Maps of the frequency of occurrence of moderate and severe icing were produced for the months from November to April. Moderate icing was associated with air temperature $\mathrm{T}<-2.0^{\circ} \mathrm{C}$ and wind speed $\mathrm{V} \geqq 6.7 \mathrm{~m} \mathrm{~s}^{-1}$, and severe icing with $\mathrm{T}<-9.0^{\circ} \mathrm{C}$ and $\mathrm{V} \geqq 15.4 \mathrm{~m} \mathrm{~s}^{-1}$. These maps are widely used by mariners in the Atlantic Ocean. The spatial variation of icing severity in the Davis Strait, Labrador Sea, Gulf of St. Lawrence, and Grand Banks and Scotian shelf was studied by Brown and Roebber (1985). A contour plot of annual mean ice accretion thickness was produced using all available ship icing reports from the period 1970-1984. This map is of interest to marine climatologists. Contours of the percent frequency of moderate and heavy (icing rate $I \geqq$ $\left.0.125 \mathrm{~cm} \mathrm{~h}^{-1}\right)$ ship icing potential in waters east of Canada (Mortsch et al., 1985) will probably be more interesting for mariners on ships operating in this area. The icing potential was computed using climatological data on the sea surface temperature (SST), air temperature, wind speed, wave height, and seawater salinity, along with a computerized version of the nomogram of Kachurin et al. (1974) described in Godard (1977) and Macdonald and Jessup (1985).

\subsection{Mapping forecast icing rates on sea-going ships}

The icing rate on ships can be estimated using the weather and sea parameters which result in the splashing of a ship with spray and ice growth on wet ship surfaces. If the appropriate relationships are used in conjunction with the analyzed meteorological and oceanographic fields, one might hindcast icing severity over the ocean and produce a map of actual icing intensity. Similarly, icing rates can be predicted using the appropriate relationships between the ice growth 
Table 1. The degree of icing severity as a function of the air temperature and wind speed (Borisenkov et al., 1969; Borisenkov and Pchelko, 1972).

\begin{tabular}{lcll}
\hline $\begin{array}{c}\text { Degree of icing } \\
\text { severity }\end{array}$ & $\begin{array}{c}\text { Icing } \\
\text { rate } \\
\text { tonnes } / \mathrm{h})\end{array}$ & \multicolumn{1}{c}{$\begin{array}{c}\text { Air temperature } \\
T_{a}\left({ }^{\circ} \mathrm{C}\right)\end{array}$} & $\begin{array}{l}\text { Wind speed } \\
U_{10}\left(\mathrm{~m} \mathrm{~s}^{-1}\right)\end{array}$ \\
\hline light & $<1.5$ & $T_{a} \leqq-3.1^{\circ} \mathrm{C}$ & $U_{10}<9 \mathrm{~m} \mathrm{~s}^{-1}$ \\
& & $-3^{\circ} \mathrm{C}<T_{a}<0^{\circ} \mathrm{C} \quad \& \quad$ & $U_{10} \geqq 0$ \\
heavy & $1.5-4.0$ & $-8.0^{\circ} \mathrm{C}<T_{a} \leqq-3.0^{\circ} \mathrm{C} \&$ & $9 \mathrm{~m} \mathrm{~s}^{-1}<U_{10}<15 \mathrm{~m} \mathrm{~s}^{-1}$ \\
very heavy & $\geqq 4.0$ & $T_{a} \leqq-3.1^{\circ} \mathrm{C} \quad \& \quad$ & $U_{10} \geqq 15 \mathrm{~m} \mathrm{~s}^{-1}$ \\
& & $T_{a} \leqq-8.1^{\circ} \mathrm{C} \quad \&$ & $U_{10} \geqq 9 \mathrm{~m} \mathrm{~s}^{-1}$ \\
\hline
\end{tabular}

rates and forecast meteorological and oceanographic fields. Maps of forecast icing rates can be produced once the spatial distribution of the predicted values of icing rates have been computed over the ocean.

Borisenkov and Pchelko (1972) discussed the forecasting of ship icing using the synoptic method. They did not introduce any Soviet technique for mapping icing rates on ships over the ocean. However, the extensive development of Soviet numerical forecasts of ship icing was acknowledged. Tsvietukhin (1977) presented this numerical approach in detail. The hydrometeorological criteria of Borisenkov et al. (1969) defined in terms of air temperature and wind speed, were applied to determine several categories of icing rate (Table 1). The proposed numerical algorithm requires, as input data, the air temperature and the air pressure from two levels of the atmosphere (surface and $400 \mathrm{mb}$ or $500 \mathrm{mb}$ ). The computations were made for a numerical grid of $22 \times 16$ points $(300 \mathrm{~km}$ spacing) superimposed on the North Atlantic Ocean between Greenland, the North Pole, Scandinavia, and the Taymyr Peninsula. At the surface, the average error for the 24-hour forecast of air pressure was $25 \%$ of a factual value (standard deviation $\mathrm{SD}=0.5-0.6 \mathrm{kPa}$ ) and for air temperature $30 \%\left(\mathrm{SD}=3-4^{\circ} \mathrm{C}\right)$. In order to predict the conditions of ship icing, values of air temperature and wind speed are used directly to determine the appropriate value of the hydrometeorological complex for each grid cell. Then, the areas of occurrence of the predicted icing rates are distinguished by analyzing the values of these complexes favourable for ship icing. An

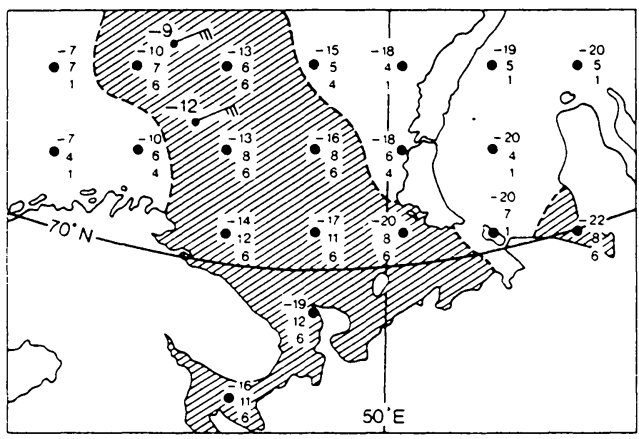

Fig. 1. Soviet 24-h forecast of ship icing for 0300 Moscow time, 15 January 1975 (according to Tsvietukhin, 1977). The area of heavy icing is hatched. The numbers show (from the top) the air temperature, wind speed (in $\mathrm{m} \mathrm{s}^{-1}$ ) and the values of the hydrometeorological complex favourable to icing according to the categorical scale of Borisenkov et al. (1969).

example of such a map of forecast icing intensity is given in Fig. 1. We suspect that sea ice was not taken into account by the Soviets. By the middle of January, large areas of the polar seas should be covered with sea ice. However, the map predicts icing of ships everywhere, even though it is well-known that spray icing does not occur in fields of sea ice. Consequently, this approach certainly might be improved through the use of ice limit data (e.g., contours of the ice boundary of pack ice of $5 / 10$ concentration, or the limit of all known sea ice other than new ice).

The Wise and Comiskey (1980) version of Mertins' (1968) nomogram was recently applied (Feit, 1985) with a grid size of 2.5 degrees latitude and longitude, in the Gulf of Alaska using the National Meteorological Centre (NMC) 
spectral medium range forecast model output for several meteorological and oceanographic fields. The algorithm requires the input in the form of analyses of the model $1000 \mathrm{mb}$ air temperature and geostrophic wind fields. The friction effects of the ocean surface are considered by reducing the wind speed by $20 \%$. The analyzed actual sea surface temperature field is also used for the computations. Four icing rate (I) categories are distinguished: 1 . NO ICING (I $\leqq 0.08 \mathrm{~cm} \mathrm{~h}^{-1}$; I $\leqq 0.1$ inch per 3 hours $)$, 2. LIGHT $(0.08<\mathrm{I} \leqq$ $0.21 \mathrm{~cm} \mathrm{~h}^{-1} ; 0.1<\mathrm{I} \leqq 0.25$ inch per 3 hours), 3 . MODERATE $\left(0.21<\mathrm{I} \leqq 0.42 \mathrm{~cm} \mathrm{~h}^{-1} ; 0.25<\right.$ I $\leqq 0.5$ inch per 3 hours), and 4 . HEAVY (I $>$ $0.42 \mathrm{~cm} \mathrm{~h}^{-1} ; \mathrm{I}>0.5$ inch per 3 hours). The model evaluation, based on a limited number of observations of icing, taken by Alaskan fishing vessels, showed that the 24-hour forecast of the icing rate was substantially underestimated by one icing rate category. Eliminating the friction effects on the wind speed improved the model performance (Feit, 1985).

The NOAA Experimental Ice Accretion Chart (Fig. 2) has been produced daily since the winter of 1986-87. The chart is based on the categorical icing rate predictor (PR) given by the formula (Overland et al., 1986):

$$
\begin{gathered}
P R=V\left(T_{f}-T_{a}\right) /\left(1+0.4\left(T_{w}-T_{f}\right)\right) \\
m^{\circ} \mathrm{Cs}^{-1}
\end{gathered}
$$

where $T_{f}$ is the freezing point of seawater (in $\left.{ }^{\circ} \mathrm{C}\right), T_{w}$ and $T_{a}$ are the water surface and air temperatures (in ${ }^{\circ} \mathrm{C}$ ), respectively, and $\mathrm{V}$ is the wind speed (in $\mathrm{m} \mathrm{s}^{-1}$ ). Three icing rate categories were applied: 1 . LIGHT ICING (I $<0.7 \mathrm{~cm} \mathrm{~h}^{-1}$; PR $\left.<20.6 \mathrm{~m}^{\circ} \mathrm{C} \mathrm{s}^{-1}\right), 2$. MODERATE $(0.7 \leqq \mathrm{I}<$ $\left.2.0 \mathrm{~cm} \mathrm{~h}^{-1} ; 20.6 \leqq \mathrm{PR}<45.2\right)$, and, 3. HEAVY (I $\geqq 2.0 \mathrm{~cm} \mathrm{~h}^{-1} ; \mathrm{PR} \geqq 45.2$ ). The model is loaded with the analyzed field of sea surface temperature and the NMC Spectral Forecast Model output for the air temperature and wind speed at the surface. To date, the NOAA charts are probably the only ones used for predicting the icing rates on ships in the West. The NOAA approach seems to be easier to use than the Soviet-made maps introduced by Tsvietukhin (1977). However, since the Soviets did not publish reports on ship icing in 1980-1982, one cannot evaluate their most recent routine techniques for mapping the icing of ships.

Recently, Macdonald and Jessup (1985) tested the suitability of the freezing spray forecast system produced by the MEP Company for predicting and mapping the ice growth rates on ships operating in waters east of Canada. The categorical icing rates of Mertins (1968) were used to distinguish the icing intensity for mapping purposes. The predicted icing rates were calculated over a $21 \times 20$ grid (spacing $254 \mathrm{~km}$ ) using a computerized version (Godard, 1977) of the nomogram of Kachurin et al. (1974). The model of Kachurin et al. (1974) (hereafter the K model) requires the wind speed, air and sea

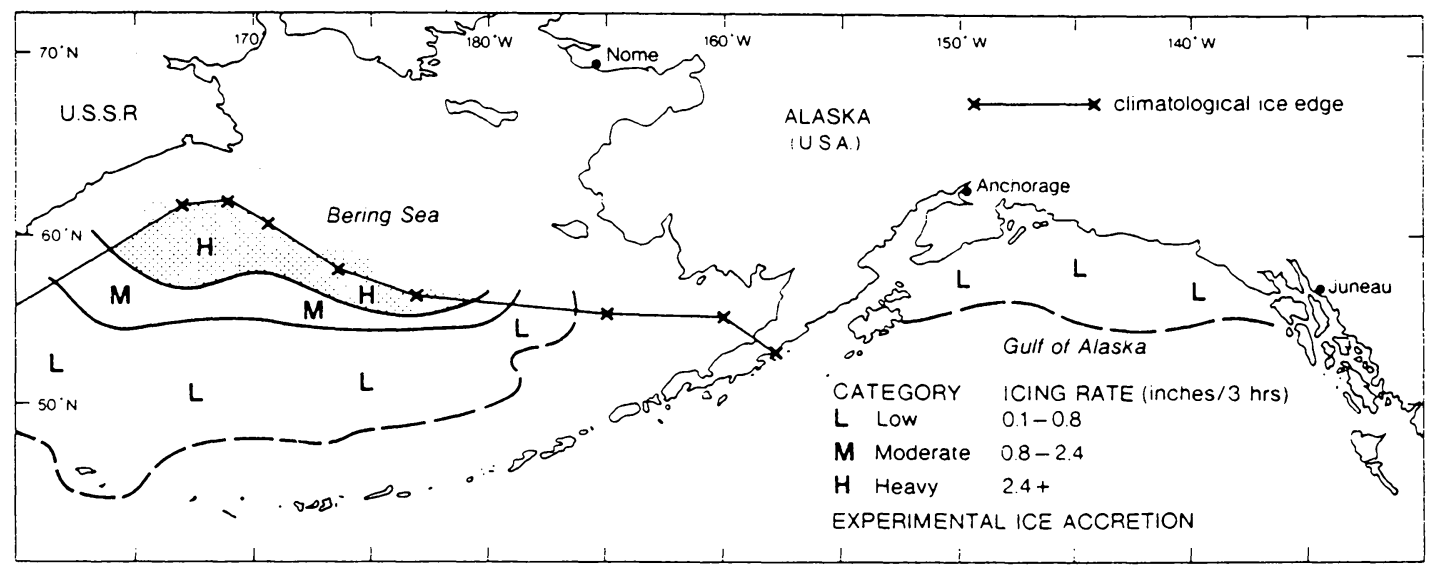

Fig. 2. A part of the NOAA 24-h icing forecast for ships (valid 12Z, 22 March 1987) (redrawn from a map provided by James Overland). 
surface temperatures and seawater salinity as input parameters. For several forecast projection times $(0,12,24$ and 16 hours), the $1000 \mathrm{mb}$ wind speed and surface air temperature fields were used from the Canadian Meteorological Centre (CMC) analyses/forecasts. The SST data were obtained from the latest CMC analyses, and this parameter was assumed to remain constant during the forecast period. The seawater salinity was assumed to be equal to 35 PPT for all ocean-located grid points. An example of the output of the MEP Company model is given in Fig. 3. The system takes into account the sea ice, and the icing intensity is assumed to be equal to 0 in sea ice-covered waters.

Because several ships have capsized due to icing in waters east of Canada (Shellard, 1974), reliable and accurate forecasts of ice growth intensity on ships are badly needed. The MEP Company system for forecasting and mapping spray icing on ships has been found useful for predicting icing rates in the cold waters east of

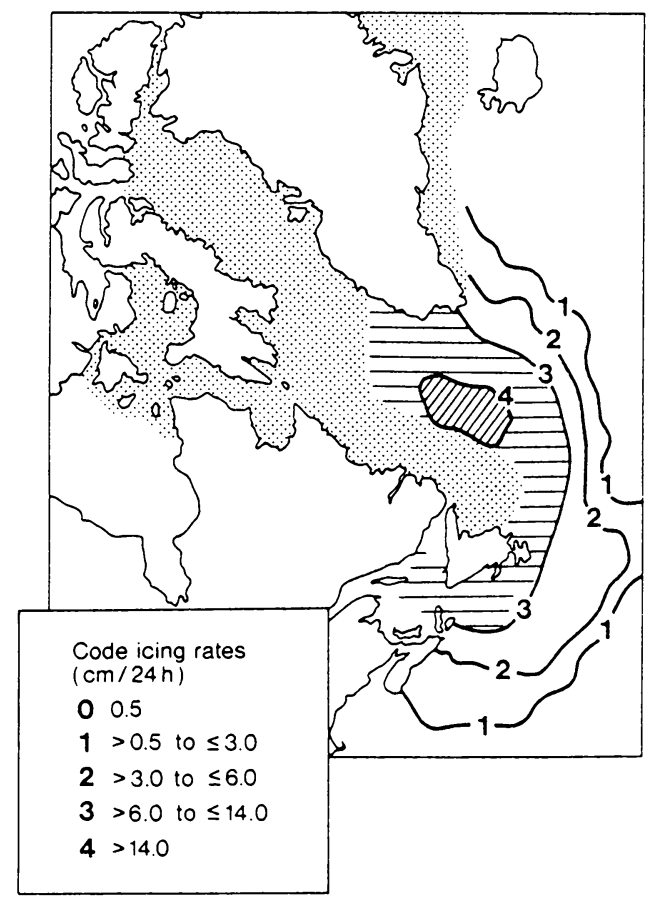

Fig. 3. Sample output from the freezing spray forecast system. Contours of icing severity class as defined in the text. Stippled areas denote ice-covered waters (redrawn from Macdonald and Jessup, 1985).
Canada. However, the results of careful studies of Soviet reports on ship icing (Zakrzewski and Lozowski, 1987b) and analysis of the $\mathrm{K}$ model (Zakrzewski and Lozowski, 1987a) have led us to question the applicability of the nomogram of Kachurin et al. (1974) for predicting the ice growth rate on ships. This nomogram was produced on the assumption that the ice growth rates on a metallic cylinder located somewhere on a medium-sized fishing vessel (of Soviet type) are well correlated with the increments of the total ice load on the entire vessel (in tonnes per hour). No information on the location of the cylinder is given except that the cylinder is oriented normal to the spray flux. The $\mathrm{K}$ model considers the flux of sensible heat with the impinging spray, but the calculations of the spray flux to the object are based on the questionable assumption that the liquid water content in the spray cloud, $w$, depends only on the wave height according to the formula:

$$
w=\xi \cdot H
$$

Here, $\xi=10^{-8} \mathrm{~g} \mathrm{~cm}^{-4}$ is a specially chosen constant and $H$ is the wave height. However, the data set and formula of Borisenkov et al. (1975) show that the liquid water content in the cloud of spray on the ship deck changes rapidly with height. Zakrzewski (1986) has also shown that for a given ship, the spray flux depends strongly on height above the ship deck and on the object's location on the deck. Neglecting these two factors will result in large errors and will certainly affect the icing rate.

The spray flux also varies with the ship speed and heading. Kachurin et al. (1974) considers a ship moving with a speed of 6-8 knots (3.1 to 4.1 $\mathrm{m} \mathrm{s}^{-1}$ ) and with a heading from $180 \mathrm{deg}$ (precisely into the waves) to $140 \mathrm{deg}$ (into the waves). Other values of ship motion parameters are not accounted for because the value of the constant $\xi$ given in Equation (2) is applicable only for the quoted values of ship speed and heading.

The ice growth rate on the entire Soviet trawler (in tonnes per hour), as measured on several ships, was correlated by Kachurin et al. (1974) with the output of the K model given in 
the form of an icing rate (in $\mathrm{cm} \mathrm{h}^{-1}$ ). Kachurin et al. claimed an extremely good fit (correlation coefficient $r=0.96 \pm 0.02$ ) and very small scatter for more than 50 cases studied. We believe that such a close correlation is, in fact, unrealistic. While we must assume the reliability of the sets for the air-sea parameters, we can examine critically the measured ice growth rates on the ships.

First, it was found that data from fishing vessels are mixed with the data from patrol boats including the Japanese patrol boats "Chitose" and "Yubari" (Tabata et al., 1963). Since the generation of spray depends very much on the ship type, such a practice is not to be recommended, especially since these patrol boats during collecting of the field data used by Kachurin et al. were moving with speeds of up to 12.5 knots $\left(7 \mathrm{~m} \mathrm{~s}^{-1}\right)$. Under such conditions the quoted 6-8 knots limitation of ship speed does not hold at all, and spray flux to the object will be much larger than calculated by the $\mathrm{K}$ model. Consequently, the predicted icing rate should differ from the model output. It should also be noted that the total ice loads on the vessels were estimated visually (Tabata et al., 1968, Fig. 2a and $2 \mathrm{~b}$ ). The accuracy of the other field data is even more questionable. Among others, field data from the fishing trawlers "Boksitogorsk", "Sievsk", and "Siebiezh" (Bering Sea, January 1965) were used to obtain the quoted correlation. Precise measurements were not conducted on these ships either. All of them sank in a severe icing storm on January 19, 1965 (accompanied by six Japanese ships) with the loss of all crew members but one (Shellard, 1974; Aksyutin, 1979). Instead, the total icing rates on these ships were only roughly estimated (Netchaev, 1967; Tsoy, 1968) using the static ship stability criteria for fishing vessels of the same type.

Taken all together, the nomogram of Kachurin et al. (1974) based on such questionable ship data seems to be far from being ideal for use in the forecasting of icing. Since the MEP Company forecasting system for ship spray icing has already been tested positively in operation, the only thing necessary to improve it is to replace the suspect nomogram of Kachurin et al.
(1974) by another, more reliable algorithm for calculating the ice growth rates on ships.

\section{An Integrated Ship Spraying/Icing Model}

This is a brief description of a new mathematical model for the growth of spongy, saline ice developed by Zakrzewski and Lozowski (1987a) (hereafter, the ZL model). The ZL model has already been introduced to an international audience during the Ninth POAC-87 Conference in Fairbanks (August 1987) and to a Canadian audience during the Second Workshop on Operational Meteorology, Halifax (October 1987) (Zakrzewski et al., 1987b). Basically, the $\mathrm{ZL}$ model is designed to calculate the timeintegrated ice growth rates on the vertical front face of the superstructure of a medium-sized fishing vessel. The icing model includes the improved ship spraying model of Zakrzewski et al. (1987a).

\subsection{Water delivery to the object}

The improved version (Zakrzewski et al., 1987a) of the ship spraying model of Zakrzewski (1987) was used to calculate the spray flux to the front face of the superstructure (hereafter referred to as the object) of an medium-sized fishing vessel of the Soviet type (Fig. 4). Since the details of this computer model are beyond the scope of this paper, we shall only mention that the time-averaged spray flux (in $\mathrm{kg} \mathrm{m}^{-2}$ $\min ^{-1}$ ), is calculated over the object's surface

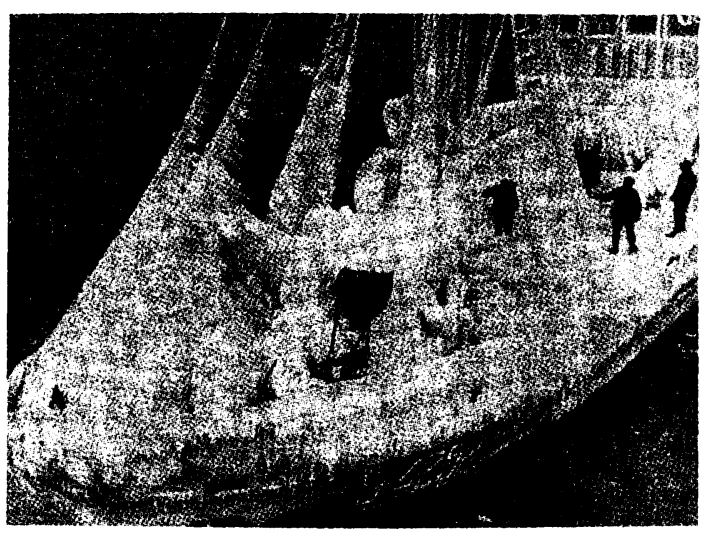

Fig. 4. The MFV "Piarnu" on return to Tallin from the cold Baltic Sea in 1969 (from Aksyutin, 1979). 
using a $7 \times 13$ numerical grid (spacing $0.5 \mathrm{~m}$ ) superimposed on it. The spray flux is computed by considering: 1 . the location of the centre of each grid cell on the ship, 2. the location of the spray source, 3 . the wind velocity, 4 . the fetch, 5. the ship speed, 6. the ship heading, and 7. the spray droplet diameter. The latter is assumed to be the median volume diameter of droplets in the central part of the spray cloud generated by the ship (calculated from the field data of Panov (1976)).

The spraying model is applicable to a ship of the above type under wind speeds equal to, or greater than, $9 \mathrm{~m} \mathrm{~s}^{-1}$, this being the minimum value for which the front face of the superstructure is sprayed. In addition to the direct spray fluxes, the spraying model calculates the trajectories of the droplets hitting the centres of each grid cell within the spraying zone, and the duration of spray flight to each wetted grid cell.

\subsection{Water and salt transport down the super- structure wall}

Because of the large values of the spray fluxes to the object, the long duration of spraying, and the short breaks between two successive sprayings (Zakrzewski, 1987 and Zakrzewski et al., 1987a), it is assumed that the spray is delivered continuously with a water supply rate, $R_{i, j}$ (in $\mathrm{kg} \mathrm{m}^{-2} \mathrm{~s}^{-1}$ ) to a given grid cell.

Between the crystals of pure ice in the resulting accretion, there is entrapped brine. This makes the ice spongy. It is assumed that over a specified short time interval, $\Delta t$, the ice growth rate, $I$, is constant, and that the ice density, salinity, and sponginess (defined here as the solid fraction of the accretion) do not change. The equation for the increment of the accretion mass over a given grid cell is:

$$
\hat{R}_{i, j}=\hat{R}_{i, j}+I_{i, j}
$$

where $\dot{R}_{i, j}$ is the mass of brine entrapped within the ijth grid cell over the time interval $\Delta t, I_{i, j}$ is the icing rate for pure ice multiplied by $\Delta t$, and $\hat{R}_{i, j}$ is the increment of the total mass of the spongy deposit. $\dot{R}_{i, j}$ can be defined in terms of the ice sponginess, $s_{i, j}$

$$
\dot{R}_{i, j}=I_{i, j}\left(1-s_{i, j}\right) / s_{i, j}
$$

where the ice sponginess is equal to:

$$
s_{i, j}=I_{i, j} /\left(I_{i, j}+\dot{R}_{i, j}\right)
$$

The salt balance equation for the ice deposit in the ijth grid cell is:

$$
\hat{R}_{i, j} \AA_{i, j}=\hat{S}_{i, j}\left(R_{i, j}+I_{i, j}\right)
$$

where $\dot{S}_{i, j}$ is the salinity of the brine entrapped, and $\hat{S}_{i, j}$ is the overall salinity of the accretion. Using equations (3), (5), and (6), $\dot{S}_{i, j}$ can also be expressed in terms of the ice sponginess and the overall ice salinity

$$
S_{i, j}=\hat{S}_{i, j} /\left(1-S_{i, j}\right)
$$

For any grid cell the water mass balance equation is

$$
R_{i, j}+R_{i-i, j}^{*}=\stackrel{\circ}{R}_{i, j}+I_{i, j}+R_{i, j}^{*}
$$

where $R_{i, j}$ is the direct spray flux, $R_{i-1, j}^{*}$ is the flux of shed water from the cell immediately above, $\mathscr{R}_{i, j}$ is the mass of brine entrapped, $I_{i, j}$ is the pure ice growth rate, and $R_{i, j}^{*}$ is the flux of shed water from the cell (Fig. 5). Here we have made the implicit assumption that the surface water flux is not wind driven and hence flows straight down.

The salt balance equation for the cell is:

$$
R_{i, j} S_{o}+R_{i-1, j}^{*} S_{i-1, j}^{*}=\stackrel{R}{i, j}_{i, j}+R_{i, j}^{*} S_{i, j}^{*}
$$

where $S_{0}$ is the spray salinity (assumed to be equal to the salinity of the seawater at the sea surface), $S_{i-1, j}^{*}$ is the salinity of the shed water flowing from the cell immediately above, $\stackrel{S}{i, j}_{i, j}$ is the salinity of the entrapped brine, and $S_{i, j}^{*}$ is the salinity of the shed water leaving the cell.

Panov (1976) has presented a figure giving the

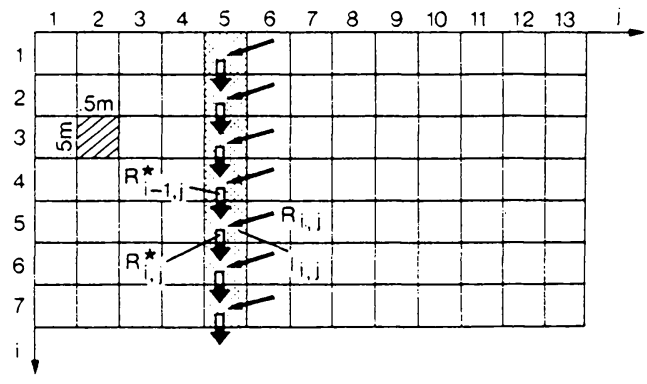

Fig. 5. Water and salt transport on the front face of the super-structure. 
distribution of the overall salinity of the accretion on the object. The Soviet data fairly well fit the regression line (Zakrzewski and Lozowski, 1987a):

$$
\hat{S}_{i, j}=-3.85 z_{i, j}+25.8 \%
$$

where $z_{i, j}$ is the height of the centre of the grid cell above the ship's deck.

The sponginess of the ice deposit on the front face of the superstructure of the RFT "Wilfred Templeman" was measured during a research cruise in waters east and south of Newfoundland during January 1987 by Zakrzewski. It shows a tendency to decrease down the wall. Our data fit the regression line:

$$
s_{i, j}=0.047 z_{i, j}+0.79
$$

where $z_{i, j}$ is the same as in Euqation (10). At present, there are no other data on the ice sponginess which could be appropriate for ships. However, we are aware that the RFT "Wilfred Templeman" is larger than an MFV of Soviet type. Therefore, as soon as other field data are available for the MFVs, we will replace Equation (11) with a relationship determined for this type of ship.

The solution of Equations (8) and (9) with the aid of Equations (5) - (7) and (10)-(11) leads to the determination for each cell of the rate of rundown to the cell immediately below (Zakrzewski and Lozowski, 1987a):

$$
R_{i, j}^{*}=\left(1-n_{i, j} / s_{i, j}\right)\left(R_{i, j}+R_{i-1, j}^{*}\right) \mathrm{kg} \mathrm{m}^{-2} \mathrm{~s}^{-1}
$$

and the overall salinity of the moving water film:

$$
S_{i, j}^{*}=\frac{R_{i, j} S_{o}+R_{i-1, j}^{*} S_{i-1, j}^{*}-n_{i, j} \hat{S}_{i, j}\left(R_{i, j}+R_{i-1, j}^{*}\right) / s_{i, j}}{\left(1-n_{i, j} / s_{i, j}\right)\left(R_{i, j}+R_{i-1, j}^{*}\right)} \%
$$

where all terms are the same as in Equations (8) and (9), and $n_{i, j}$ is the freezing fraction equal to:

$$
n_{i, j}=I_{i, j} /\left(R_{i, j}+R_{i-1, j}^{*}\right)
$$

In order to estimate the ice growth rate and freezing fraction, Equations (12) and (13) are incorporated into the heat balance equation for the icing surface.

\subsection{Heat balance equation for the icing surface}

In the ZL model, spray droplets of temperature $T_{d}$, which varies over the grid, impact on the object (Fig. 6). The temperature of the moving film of brine is assumed to be equal to the equilibrium surface temperature, $T_{s}$. It is also assumed to be homogeneous over a grid cell and throughout the thickness of the water film. If icing progresses, $T_{s}$ is equal to the freezing temperature $\left(T_{f}\right)$ of the shed water of a given salinity, $S_{i, j}^{*}$. The freezing point of this water may be given by (Makkonen, private communication):

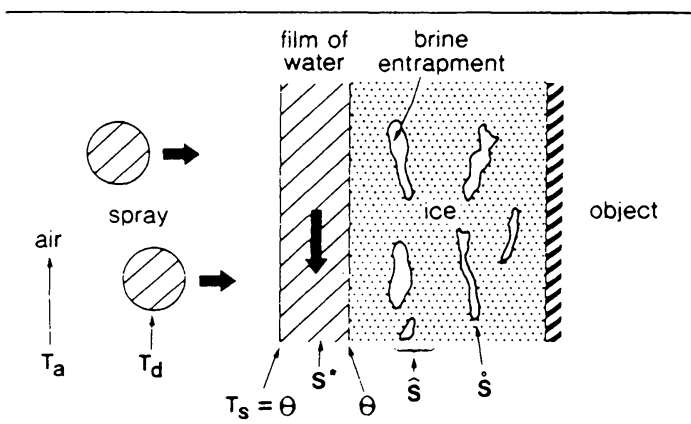

Fig. 6. Icing surface $f$ the front side of the ship superstructure.

$$
S_{b}=-T_{f} / 0.054{ }^{\circ} \mathrm{C}
$$

where $S_{b}$ is the salinity of seawater. If the heat flux through the ice deposit and the heat fluxes due to the kinetic energy of the impinging spray and aerodynamic heating are neglected, the solution of the heat balance equation for the icing surface leads to the following formula for the pure ice growth rate (Zakrzewski and Lozowski, 1987a):

$$
\begin{aligned}
I_{i, j}= & h l_{f}^{-1}\left[\left(\frac{P r}{S c}\right)^{0.63}\left(\frac{\varepsilon l_{v}}{c_{a} p}\right)\left(e_{i, j}-e_{a}\right)-\left(T_{a}-\theta_{i, j}\right)\right]+R_{i, j} l_{f}^{-1} c_{w}\left(\theta_{i, j}-\left(T_{d}\right)_{i, j}\right) \\
& -a l_{f}^{-1}\left(T_{a}-\theta_{i, j}\right)-R_{i-1, j}^{*} c_{w} l_{f}^{-1}\left(\theta_{i-1, j}-\theta_{i, j}\right) \mathrm{kg} \mathrm{m}^{-2} \mathrm{~s}^{-1}
\end{aligned}
$$


where: $\operatorname{Pr}=0.711$ and $S c=0.595$ are, respectively, the Prandtl and Schmidt numbers for air, $l_{v}$ is the latent heat of vaporization; $c_{a}$ and $c_{w}$ are the specific heat capacities at constant pressure of air and seawater, respectively, $l_{f}$ is the latent heat of fusion of pure water, $p$ is the air pressure (in $\mathrm{kPa}$ ), $\theta$ is the freezing point of shed brine, $R_{i-1, j}^{*}$ is the shed water flux from the cell immediately above, $R_{i, j}$ is the direct spray flux to the cell, $R_{i, j}^{*}$ is the flux of shed water leaving the cell, $T_{a}$ is the air temperature, $T_{d}$ is the spray impact temperature, $e_{i, j}$ is the saturation vapor pressure at the temperature $\theta$, and $e_{a}$ is the actual vapour pressure in the airstream. The saturation vapour pressure can be computed by the formula shown in Kochtubajda and Lozowski (1985):

$$
\left.e_{T}=D_{o}+T\left\{D_{1}+T\left[D_{3}+D_{4} T\right)\right]\right\} \quad \mathrm{mb}
$$

where the constants $D_{o}, D_{1}, D_{2}, D_{3}$, and $D_{4}$ are $6.10779996,4.436518521 \times 10^{-1}, 1.428945805$ $\times 10^{-2}, 2.650648471 \times 10^{-4}$, and $3.031240396 \times$ $10^{-6}$, respectively. The effect of salt on the saturation vapour pressure is neglected in our approach. $\varepsilon$ is the ratio of the molecular weights of water vapour and dry air $(\varepsilon=0.622), a$ is the linearization coefficient for the heat flux due to long-wave radiation $\left(a=4.4 \mathrm{~W} \mathrm{~m}^{-2} \mathrm{~K}^{-1}\right), h$ is the convective heat transfer coefficient, which is related to the Nusselt number, $\mathrm{Nu}$, by:

$$
h=k_{a} N u / L \quad W \mathrm{~m}^{-2} \mathrm{~K}^{-1}
$$

where $L$ is the characteristic length of the object (here, $L=4.47 \mathrm{~m}$ is used as the geometric mean dimension of an object of height $3.5 \mathrm{~m}$ and breadth $5.72 \mathrm{~m}$ ), and $k_{a}$ is the thermal conductivity of the air. Since at present there is a lack of experimental data giving the Nusselt number for such large objects as a ship superstructure, the formula of Kreith (1969) for a flat plate in a parallel airstream has been used:

$$
N u=0.036 \operatorname{Pr}^{0.33} \operatorname{Re}^{0.8}
$$

where $R e$ is the Reynolds number equal to:

$$
R e=L U_{r} / \nu_{a}
$$

where $\nu_{a}$ is the kinematic viscosity of the air, and $U_{r}$ is the relative wind speed. Using the assump- tion that the wind speed at the object height is uniform and equal to the wind speed at the $10 \mathrm{~m}$ reference level, the relative wind past the object velocity $U_{r}$, can be computed from the formula:

$$
U_{r}=\sqrt{U_{10}^{2}+V_{s}^{2}-2 U_{10} V_{s} \cos \alpha} \mathrm{m} \mathrm{s}^{-1}
$$

where $V_{s}$ is the ship speed and $\alpha$ is the ship heading.

Since the icing rate for pure ice $I_{i, j}$, is related to the freezing fraction $n_{i, j}$, and total water supply rate, Equations (16) and (14) can be used to determine the freezing fraction for a given cell.

\subsection{Spray impact temperature}

The spray impact temperature varies over the object's surface because the duration of the spray flight to each grid cell is different. For a given wind speed, fetch, ship speed and heading, the duration of spray flight, $\tau$, is found numerically by solving the equation of motion and monitoring the droplet from the spray source to the centre of the grid cell.

When heat loss due to evaporation and convection is considered, the spray temperature $T_{d}$ can be given by the formula (Stallabrass, 1980):

$$
T_{d}=T_{a}+\left(T_{w}-T_{a}\right) \exp (-k X \tau) \quad{ }^{\circ} \mathrm{C}
$$

where $T_{a}$ and $T_{w}$ are the air and sea surface temperatures, respectively, $\tau$ is time after ejection of the spray drops, and $X$ is a factor giving the effect of evaporation:

$$
X=1+\varepsilon \frac{l_{v}}{p c_{a}} \frac{e_{a}-e_{T}}{T_{a}-T}
$$

where $T$ is the instantaneous spray temperature, $e_{T}$ is the saturation vapour pressure at temperature $T$, and $e_{a}$ is the actual vapour pressure in the airstream.

The coefficient $k$ in Equation (22) is given by the formula:

$$
k=\frac{6 N u_{d} k_{a}}{\rho_{w} c_{w} d^{2}}
$$

$N u_{d}$ is the droplet Nusselt number equal to (Michieev and Michieeva, 1973):

$$
N u_{d}=\left[\begin{array}{lll}
0.49 R e^{0.50} & \text { for } & R e<10^{3} \\
0.24 R e^{0.60} & \text { for } & R e>10^{3}
\end{array}\right.
$$


where $\operatorname{Re}$ is the droplet Reynolds number, $d$ is the droplet diameter, and $\rho_{w}$ is the density of seawater. The median volume diameter (1.25 $\mathrm{mm}$ ) of collision-generated spray calculated from the data of Panov (1976) is used.

\subsection{Spongy saline ice deposit thickness distribu- tion}

Equation (16) can be used to calculate the time-averaged local rate (in $\mathrm{kg} \mathrm{m}^{-2} \mathrm{~h}^{-1}$ ) of the growth of pure ice for a given cell if over a given hour of an icing event the air-sea and ship motion parameters involved in the ice growth are unchanged. The icing rate for the spongy saline ice deposit during the hour is:

$$
H_{i, j}=\bar{I}_{i, j}\left(\frac{1}{\rho}+\frac{1-s_{i, j}}{\rho_{i, j} s_{i, j}}\right) \mathrm{mh}^{-1}
$$

where $\bar{I}_{i, j}$ is the time averaged local icing rate, $s_{i, j}$ is the ice sponginess, $\rho$ is the density of pure ice, and $\stackrel{\circ}{i, j}_{i}$ is the density of the brine entrapped in the ice deposit. $\dot{\rho}_{i, j}$ can be estimated by the formula:

$$
\begin{array}{r}
\stackrel{\circ}{\rho}_{i, j}=1000 \rho_{s} /\left(\dot{S}_{i, j}+\rho\left(1000-\dot{S}_{i, j}\right) / \rho_{p}\right) \\
\mathrm{kg} \mathrm{m}^{-3}
\end{array}
$$

where $\dot{S}_{i, j}$ is the salinity of brine (in parts per thousand), $\rho_{s}$ is the density of the salt in seawater, equal to approximately $3290 \mathrm{~kg} \mathrm{~m}^{-3}$, and $\rho_{p}$ is the density of pure water, equal to $1000 \mathrm{~kg} \mathrm{~m}^{-3}$.

\section{Map Projection and Database}

The main objective of our study is to plot the spatial distribution over the ocean of the icing rates on a real ship. Consequently, we needed an appropriate mapping technique and original field data on the air and sea parameters which relate to the splashing of a ship and the ice growth on it.

\subsection{Map projection}

In order to plot the contours for the ice accretion rates on the same cartographic projection as that of the Atmospheric Environment Service of Canada weather charts, a polar stereographic secant (PSS) projection was chosen. The graphics for these maps were custom designed for this project.

\subsection{Selecting the area}

Because ships very often experience icing in the cold waters east of Canada, and because original air-sea data sets for this geographical region are available, we considered the entire region between the meridians of $070^{\circ} \mathrm{W}$ and $040^{\circ} \mathrm{W}$, and the parallels of $40^{\circ}$ and $65^{\circ} \mathrm{N}$ for our investigation. However, since we wanted for the present only to check the applicability of the ZL model for mapping ice rates on ships over the ocean, the area was much reduced. After revision of the data sets, and finding that large ocean areas are data-free (except for air pressure) due to the scarcity of ship reports, the area under consideration was finally limited to $065^{\circ} \mathrm{W}$ to $045^{\circ} \mathrm{W}$ and $42^{\circ} \mathrm{N}$ to $50^{\circ} \mathrm{N}$. The numerical grid resolution is $1^{\circ}$ in latitude $(111 \mathrm{~km})$ and $2^{\circ}$ in longitude $\left(165 \mathrm{~km}\right.$ at $42^{\circ} \mathrm{N}$ and $143 \mathrm{~km}$ at $50^{\circ} \mathrm{N}$ ).

\subsection{The Database for the Air-sea Parameters}

Weather charts (surface analyses) and wave analysis charts, produced by Canadian Forces Metoc Centre in Halifax, from the winter of 1984-85, were reviewed in order to select days with relatively strong winds and an air temperature below $-2^{\circ} \mathrm{C}$ within the chosen area. We finally chose the maps of February 5 and 6 (0000Z) and February 7 and 8 (1200Z), extracting the grid point data by hand.

The surface wind speed was obtained from surface analysis charts, using mostly ship reports and weather buoy data. Fortunately, for most of the area, plenty of such data were available. If there was no information from ships or buoys, the surface wind speed at a given grid point was estimated, using the geostrophic wind scale and the formula:

$$
U_{s}=B U_{g} \mathrm{~m} \mathrm{~s}^{-1}
$$

where $U_{8}$ is the surface wind, $U_{g}$ is the geostrophic wind speed, and $B$ is a scaling factor equal to:

$$
B=\left(U_{s}\right)_{s} /\left(U_{g}\right)_{s}
$$

where $\left(U_{s}\right)_{s}$ is the wind speed reported from the nearest ship or buoy, and $\left(U_{g}\right)_{s}$ is the geostrophic wind speed for the ship or buoy. 
The wind direction was obtained from the ship reports, either directly or by interpolation if the ships were close to a given grid point. Otherwise it was determined from the isobars. In the latter case, the effect of the surface friction was taken into account by adjusting the wind direction by $30^{\circ}$.

The air temperature was obtained from the surface analysis charts as reported from ships. For the area north of the Grand Banks, where very few ship reports were available, the air temperature was extrapolated from the land stations and availabable ship data.

The sea surface temperatures were obtained from the climatological monthly mean data of Mortsch et al. (1985) for February.

The salinity of seawater was assumed to be uniform over the entire area and equal to $33 \%$.

The ice limit defined here as the limit of the sea ice was obtained from the appropriate wave analysis chart.

The fetch defined here as the range from a grid point to the nearest land point (exclusive of small islands if the fetch was larger than 100 nautical miles) or to the ice edge, in the upwind direction, was determined using the land and ice edge data and the wind direction estimates. Fetch is required because the height and period of the significant waves involved in the spraying process are fetch dependent.

\subsection{Ship motion parameters}

Several control runs of the $\mathrm{ZL}$ model have shown that, when a ship moves precisely into the waves ( $\alpha=180^{\circ}$ ), the icing rate on the ship's superstructure is a maximum. The tests also showed that the total ice load on the entire ship, calculated using a relationship between the superstructure icing rates and the total ice load (Zakrzewski, 1986), was also a maximum for a ship heading of $180^{\circ}$. Since we wish to map the maximum potential icing rates, all our runs were performed only for ships moving precisely into the waves $\left(\alpha=180^{\circ}\right)$.

The icing rate depends on the spray flux and in cold waters it increases with the ship speed. Therefore, the maximum ship speed appropriate for the performance of a medium-sized fishing vessel of Soviet type, operating in a given wind speed, were used as estimated by Zakrzewski (Table 2). Since the spray hits the ship superstructure only if the wind speed is equal to or greater than $9 \mathrm{~m} / \mathrm{s}$, there is no icing on the ship superstructure for wind speeds $U_{10} \leqq 8 \mathrm{~m} / \mathrm{s}$.

\section{Results and Discussion}

Maps of the maximum potential icing rates (in $\mathrm{cm} \mathrm{h}^{-1}$ ) for four synoptic cases are given in Fig. 7. On February 5 (0000Z) 1985, case \#1, the most severe icing conditions occurred south of Newfoundland $\left(I \geqq 0.7 \mathrm{~cm} \mathrm{~h}^{-1}\right)$. Conditions favourable to severe icing also occurred between the west coast of Newfoundland and the ice edge. No icing was forecast in the central and southern parts of the Grand Banks or in the southern part of the Scotian Shelf. Similarly, no icing occurred east of the $045^{\circ} \mathrm{W}$ meridian.

On February $6(0000 \mathrm{Z})$, case \#2, icing is forecast for the entire area between the $063^{\circ}$ and $051^{\circ} \mathrm{W}$ meridians, and south of Newfoundland, with the maximum rate $\left(I \geqq 0.6 \mathrm{~cm} \mathrm{~h}^{-1}\right)$ just off the Newfoundland coast. Conditions favourable to ship icing also occurred in the Grand Banks, with two small secondary areas of high icing rates just east of the ice edge. A very small area, between the west coast of Newfoundland and the pack ice edge, is identified as having conditions favourable to severe icing. The waters southwest from Nova Scotia and southeast from the Grand Banks were, according to our map, free of the risk of ship icing.

On February 7 (1200Z), case \#3, conditions

Table 2. Estimates of the maximum ship speed fr various wind speeds.

\begin{tabular}{cccc}
\hline $\begin{array}{c}\text { Wind speed } \\
\left(\mathrm{m} \mathrm{s}^{-1}\right)\end{array}$ & $\begin{array}{c}\text { Ship speed } \\
\left(\mathrm{m} \mathrm{s}^{-1}\right)\end{array}$ & $\begin{array}{c}\text { Wind speed } \\
\left(\mathrm{m} \mathrm{s}^{-1}\right)\end{array}$ & $\begin{array}{c}\text { Ship speed } \\
\left(\mathrm{m} \mathrm{s}^{-1}\right)\end{array}$ \\
\hline $0-5.0$ & 4.67 & $17.2-20.7$ & 2.54 \\
$5.1-10.7$ & 4.37 & $20.8-24.4$ & 1.80 \\
$10.8-13.8$ & 3.86 & $24.5-28.4$ & 1.25 \\
$13.9-17.1$ & 3.00 & $28.5-32.6$ & 0.55 \\
\hline
\end{tabular}




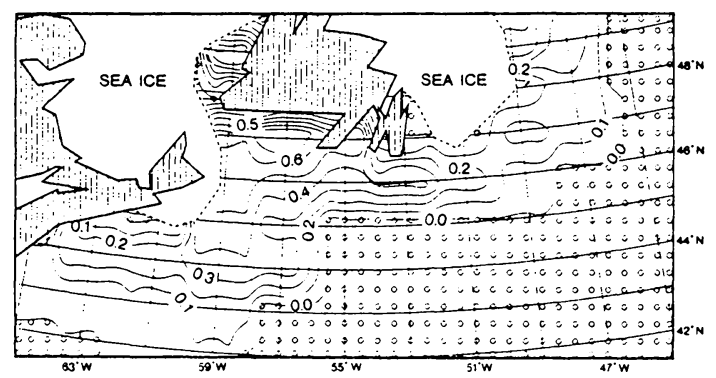

(a)

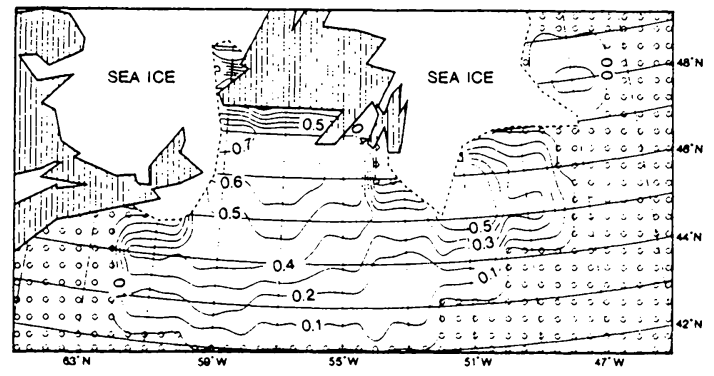

(b)

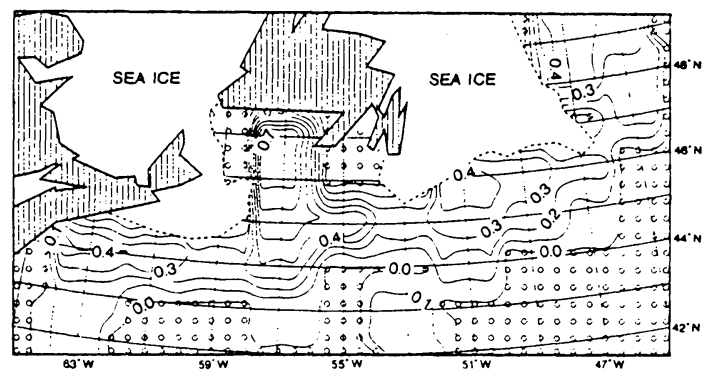

(c)

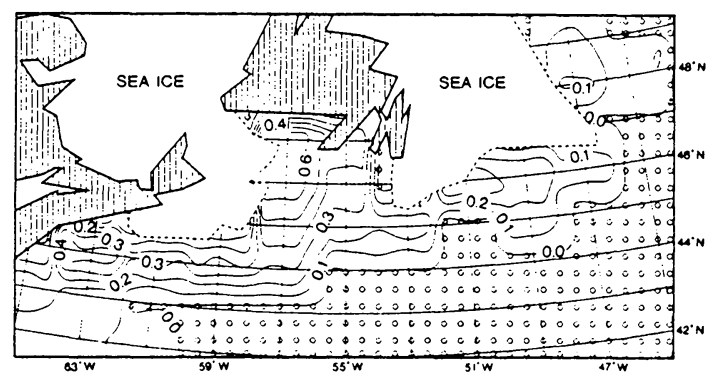

(d)

Fig. 7. Maps of the maximum potential icing rates in the Northwest Atlantic Ocean (in $\mathrm{cm} \mathrm{h}^{-1}$ ).
(a) 5 Feb. $1985,0000 Z$
(b) 6 Feb. 1985, 0000Z
(c) 7 Feb. $1985,1200 Z$
(d) 8 I Eeb. $1985,1200 Z$

favourable to ship icing occurred almost everywhere in the area covered by our map. At that time, the most severe icing conditions occurred south of Newfoundland, east of Nova Scotia, and in the central part of the Grand Banks just off the ice edge, at $45-46^{\circ} \mathrm{N}$ and $048-052^{\circ} \mathrm{W}$. Another small area of relatively severe icing is visible at the very northeast of the map $\left(48-50^{\circ} \mathrm{N}\right.$ and $047-045^{\circ} \mathrm{W}$ ). Since the Gulf of St. Lawrence is entirely covered with sea ice, no icing occurs there. No icing is evident either in the ice-free areas southeast of the Grand Banks, and between $42-43^{\circ} \mathrm{N}$ and $059-061^{\circ} \mathrm{W}$. A very small area with conditions unfavourable to icing can be seen south of the Avalon Peninsula $\left(46-47^{\circ} \mathrm{N}\right.$ and along the $055^{\circ}$ meridian).

The last map (February 8, 1200Z) shows that conditions favourable to severe icing occurred just south of Newfoundland and south of Nova Scotia. In both areas the maximum icing rate was $\mathrm{I} \geqq 0.5 \mathrm{~cm} \mathrm{~h}^{-1}$. The waters along the $42-43^{\circ}$ parallels and east of the $059^{\circ} \mathrm{W}$ meridian are icing-free. Two small areas east of the pack ice edge in the northern part of the Grand Banks (along the $47^{\circ} \mathrm{N}$ parallel, and along the $49^{\circ} \mathrm{N}$ parallel, and between $045-047^{\circ} \mathrm{W}$ ) are also free of an icing risk.

The contours of the icing rates on all four ice accretion maps show a strong effect of sea surface temperature on the icing intensity. The high water temperatures in the North Atlantic Current dramatically reduce the icing rates and, where the water temperature is greater than $6-8^{\circ} \mathrm{C}$, entirely prevent icing. The effect of the sea surface temperature is reduced only if cold air intrudes far to the south of southeast. Such a situation happened on February 6 and 7. This gave rise to non-zero icing rates in the southern part of the area $\left(42-43^{\circ} \mathrm{N}\right.$ and $\left.051-059^{\circ} \mathrm{W}\right)$.

Unfortunately, synoptic analyses of the meteorological conditions resulting in the icing patterns described above are beyond the scope of this short presentation. The model predictions were compared with the icing rate estimates obtained with the aid of Mertins' (1968) nomogram. Analyses of data from more than 30 grid points (all maps) showed good agreement.

The strong effect of sea surface temperature 
on the icing intensity can be explained by focussing on the heat balance equation of the icing surface. The sensible heat flux in this equation appears to dominate the heat transfer from the icing surface. The icing rate increases with increasing spray flux only if the spray impacting temperature is below the freezing temperature of brine on the icing surface. As $T_{w}$ increases, the spray temperature increases accordingly. Consequently, the impacting spray arrives at the superstructure not supercooled and it begins to reduce the icing rate. The threshold sea surface temperature, which begins to reduce the icing rate, is different for various wind speeds. At sea surface temperatures higher than $6-8^{\circ} \mathrm{C}$, the model predicts no icing, since the ice growth is ceased by the heat flux associated with the impinging spray. Our findings are well correlated with the data of Mertins (1968) and Pease and Comiskey (1986).

To the best of our knowledge, neither in the USA nor in the USSR, where maps of the icing rates on ships are routinely produced, is an output from a physically-based model used for plotting the charts. Our model has been developed for a realistic ship and has considered the object's geometry and the object location on a vessel. Moreover, since the model includes the ship speed and heading, it can also be used as a tactical decision-making aid for fishing vessels. Another innovative feature in our approach is that our maps are plotted for the icing rates of spongy saline accretion. By these means the effects of brine entrapment in the accretion on thyicing rate have been taken into account.

We believe that the results of our unique project might be of interest to several national organizations with a responsibility for, or a concern with, the hindcasting or forecasting of ship icing. We are confident that our present model would allow the calculation of actual or forecast ice growth rates on ships within 30 minutes if an appropriate automatic data acquisition system were available. During our final runs, the icing intensity maps were ready within one hour from the beginning of manual data acquisition from the weather and wave charts.

\section{Acknowledgements}

This project was performed with financial support for the senior author from an NSERC Strategic Grant. The authors are grateful to Mr. R. Brown (AES, Downsview) for providing us with the climatological data on sea surface temperatures. Special thanks are due to Mr. S. Porter (AES, St. John's) for providing the first author, free of charge, with a set of surface analysis and wave analysis and prognosis charts in 1985 while the author was at C-CORE. Also, we are very grateful to Dr. D. Muggeridge, Dr. R. Heidrich (MUN, St. John's), and Mr. G. Tucker (Fisheries and Oceans, St. John's) for their help and financial support for our field data collecting program in the $1986-87$ winter. Special thanks to Mr. Geoff Lester and Michael Fisher (University of Alberta) for producing the figures. Finally, we wish to thank Ms. L. Smith who carefully typed the manuscript on short notice.

\section{References}

Aksyutin, I.L., 1979: Icing of ships (in Russian). Sudostroyenye Publishing House, Leningrad, $126 \mathrm{pp}$.

Borisenkov, Ye. P., A.M. Kovrova and V.V. Panov, 1969: On the hydrometeorological complexes favourable to icing of sea-going ships. In: Hydrometeorological conditions of ship icing (in Russian). Arkticheskii i Antarkticheskii Nauchno-lssledovatiel' skii Institut, Leningrad, 70-75.

and I.G. Pchelko (eds.), 1972: Indicators for forecasting ship icing (in Russian). Arkticheskii i Antarkticheskii Nauchno-Issledovatiel'skii Institut, Leningrad. Also, 1975: CRREL Draft Translation No. 481 .

Brown, R.D. and P. Roebber, 1985: The ice accretion problem in Canadian waters related to the offshore energy and transportation. Canadian Climate Centre, Report No. 85-13, AES, Downsview, 126 pp.

DeAngelis, R.M., 1974: Superstructure icing. Mariners Weather Log, 18: 1, 1-7.

Dunbar, M., 1964: Geographical distribution of superstructure icing in the northern hemisphere. Report Misc. G-15, Directorate of Physical Research, Defence Research Board, Ottawa, Canada.

Feit, D.M., 1985: Ship superstructure ice accretion guidance forecasts. In: Proceedings International Workshop on Offshore Winds and Icing, Halifax, Nova Scotia, Oct. 7-11, 1985, 278-287.

Godard, R., 1977: Numerical prediction of sea spray accretion on ships. Report to the Atmospheric Environment Service, Downsview, Ont.

Harwood, T.A., 1960: The fallout hazard in icing 
conditions. In: Proceedings Triportite Symposium on the Technical Status of Radiological Defence in the Fleets. U.S. Naval Radiological Defence Laboratory, San Francisco, May 1960, R \& L 1: 103.

Kachurin, L.G., L.I. Goshin and I.A. Smirnov, 1974: Icing rate of small displacement fishing vessels under various hydrometeorological conditions (in Russian). Meteorologiya i Gidrologiya, No. 3, 50-60.

Kochtubajda, B. and E.P. Lozowski, 1985: The sublimitation of dry pellets used for cloud seeding. Journal of Climate and Applied Meteorology, 24: 6, 597-605.

Kolosova, N.N., 1972: Potential ship icing regions of the Chukchi Sea during the summer and fall. In: Arkticheskii i Antarkticheskii Nauchno-Issledovatiel' skii Institut, Leningrad, Trudy No. 298, 156-157. Also, CRREL Draft Translation No. 411.

- V.V. Panov and M. Ya. Zatonskii, 1971: On the methodology of preparing maps of the probability of ship icing in the polar seas. In: Theoretical and experimental studies of ship icing (in Russian). Arkticheskii i Antarkticheskii NauchnoIssledovatiel'skii Institut, Leningrad, 190-204.

Kreith, F., 1969: Principles of heat transfer. International Textbook Co., Scranton, Penn., 620 pp.

Macdonald, K.A. and R.G. Jessup, 1985: Evaluation of a freezing spray forecast system. In: Proceedings International Workshop on Offshore Winds and Icing, Halifax, Nova Scotia, Oct. 7-11, 1985, 267-277.

Mertins, H.O., 1968: Icing on fishing vessels due to spray. Marine Observer, 38: 221, 128-130.

Michieev, M.A. and I.M. Michieeva, 1973: Principles of heat transfer (in Russian). Energiya Publishing House, Moscov, 319 pp.

Minsk, L.D., 1977: Ice accumulation on ocean structures. CRREL Report 77-17, 42 pp.

Mortsch, L.D. et al., 1985: Marine Climatological Atlas - Canadian East Coast. Canadian Climate Centre, AES, Report No. 85-11, 343 pp.

Netchaev, Yu. I., 1967: Investigation of the MFV "Boksitogorsk" icing disaster. (in Russian) Morskoy Flot, 1, 25-27.

Overland, J.E., C.H. Pease, R.W. Preisendorfer and A.L. Comiskey, 1986: Prediction of vessel icing. J. of Climate and App. Meteor., 25; 12, 1793-1806.

Panov, V.V., 1976: Icing of ships (in Russian). Arkticheskii i Antarkticheskii Nauchno-Issledovatiel' skii Institut, Leningrad, Trudy No. 336, 263 pp.

Shellard, H.C., 1974: The meteorological aspects of ice accretion on ships. World Meteorological Organization. Marine Science Affairs Report No. 10 (WMO, No. 397), Geneva, 34 pp.

Smirnov, V.I., 1972: Conditions of ship icing and anti-icing techniques (according to foreign data). In: Articheskii $i$ Antarkticheskii Nauchno-Issledovatiel' skii Institut, Leningrad, Trudy No. 298 (in Russian).
Also, CRREL Draft Translation No. 411.

Stallabrass, J.R., 1980: Trawler Icing: A compilation of work done at N.R.C. National Research Council, Mechanical Engineering Report, MD-56, NRC No. 19272, Ottawa, 103 pp.

Tabata, T., S. Iwata and N. Ono, 1963: Studies of ice accumulation on ships Part 1. Low Temperature Science, Series A, 21, 173-221. Also, 1968: NRC Tech. Translation 1318, Ottawa.

Tsoy, L.G., 1968: Analysis of the MFV "Boksitogorsk" disaster and emergencies on the MFV "Ataman." In: Theoretical and Practical Aspects of Ship Stability and Survivability of Sea-Going Ships, Transport Publishing House, Leningrad (in Russian), 208-223.

Tsvietukhin, A.S., 1977: Numerical low parameters algorithm for forecasting the conditions of vessel icing. In: Arkticheskii $i$ Antarkticheskii NauchnoIssledovatiel'skii Institut, Problemy Arktiki $i$ Antarktiki, No. 51, Leningrad (in Russian), 6-12.

U.S. Navy, Chief of Naval Operations, 1956: Marine climatic atlas of the world, Vol. I, North Atlantic Ocean. Navaev 50-1C528. 1955: Vol. II, North Pacific Ocean. Navaev 50-1 C529.

U.S. Navy Hydrographic Office, 1958: Oceanographic atlas of the polar seas, Part II, Arctic. H.O. 705, Washington, D.C.

USSR Naval General Staff, 1953: Morskoy Atlas. Vol. 11, Moscov.

Wise, J.A. and A.L. Comiskey, 1980: Superstructure icing in Alaskan waters. Pacific Marine Environmental Laboratory, NOAA Special Report, Seattle, Washington, $30 \mathrm{pp}$.

Zakrzewski, W.P., 1986: Icing of fishing vessels. Part II: Ice growth rates and simulation of icing. In: Pro ceedings 8th International IAHR Symp. on Ice, Iowa City, Aug. 18-22, 1986, 194-207.

, 1987: Splashing a ship with collisiongenerated spray. Cold Regions Sci and Tech., 14: 1, 65-83.

and E.P. Lozowski, 1987a: The application of a vessel spraying model for predicting ice growth rates and ice loads on a ship. In: Proceedings 9th International Conf. on Port and Ocean Engineering under Arctic Conditions (in press).

and - 1987b: Soviet marine icing data. Final report to the Atmospheric Environment Service, Downsview, Ont., 122 pp.

, R.Z. Blackmore, E.P. Lozowski and D. Muggeridge, 1987a: An improved ship spraying model. Unpublished manuscript, the University of Alberta, Division of Meteorology. Also, J. of Geophys. Res. (in preparation).

- - R. Blackmore and E.P. Lozowski, 1987b: Mapping the ice growth rate on sea-going ships in waters east of Canada. In: Proceedings of the 2nd Canadian Workshop on Operational Meteorology, Halifax, N.S., Oct. 14-16, 1987, 77-99. 


\section{航行中の船体への着水速度のマッピング}

\section{W.Paul Zakrzewski, Ryan Blackmore and Edward P.Lozowski}

海洋上での船体着氷ポテンシャルの为示の方法についてのレビューがまず行われる。特に着氷の㛚 といら観点からこの問題を取り上げる。

船体の上部構造物への塩分を含んだ海水の着水成長についての新しいモデルが詳しく早示される。こ のモデルによって，しぶきをあびる船体の前面の着办速度が計算される。板を流れ落ちる水膜の塩分濃 度や氷の粗度も考慮される。このモデルは入力データとして船の速度と方向, 気温, 海水の塩分濃度, 海水の表面温度，風速拉よび風の吹送距離を会む。このモデルを用いてカナダの東側の泠水域における 船体着氷速度の分布が数值的に計算される。これらの最初の結果は, 白動データ補捉システムが利用で きる場合には，このモデルが船体着氷速度の恒常的な予報（あるいは過去の解析）に応用できることを 示している。 